\title{
人血清中のコレステロールとビタミン $\mathrm{E}$ \\ との関連性について
}

$\begin{array}{llllll}\text { 平井 } & \text { 子和 } & \text { 梶 谷 } & \text { 佳 } \\ \text { ** } \\ \text { 風呂田 } & \text { 晃** } & \text { 宮 } 川 \text { 定 } & \text { 吉** }\end{array}$

血中コレステロール（Cho）は動脈硬化の危険因子 であり, 食事性因子によって変動し, 特に高度不飽和脂 肪酸の摂取量によって低下寸るといわれている。他方高 度不飽和脂肪酸の過酸化物が動脈硬化等の疾病に関与 乙, 動脈硬化の程度が進行すると共に動脈壁中の過酸化 脂質の量の増加が報告されている。又, 過酸化脂質の生

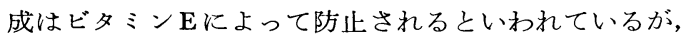

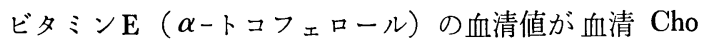
值と相関することが健常者や動物実験（ネズミ）で報告 されている。

そこで今回，動脈硬化に関連する疾患を有する者につ いて血清 Cho 值とビタミン $\mathrm{E}$ 值及び過酸化脂質との関 連性を検討した。更に, 血清中の過酸化脂質の新しい測 定方法の検討として, 食用油の劣化度測定方法である極 性画分䖝光量值の測定も検討した。

[方法]当センター受診者で健常者及び高 Cho 血者, 高脂血者・高血圧者の計 32 人（33～76歳）について，早 朝空腹時に採血して検体とした。Cho は酵素法を, 常法 としての過酸化脂質の測定には八木法（TBA 值）を用 いた。ビタミン $\mathrm{E}$ の同族体 $(\alpha-, \beta-, \gamma-, \delta$-トコフェロー ル）及び過酸化脂質の螢光量值は高速液体クロマトグラ フィーで分離定量した。

高速液体クロマトグラフィー分析条件

カラム : Lichrosorb SI-60 $(5 \mu \mathrm{m}, 4 \mathrm{mmi} . \mathrm{d} . \times 250 \mathrm{~mm})$

移動㬝 : n-ヘキサン・イソプロパノール $(100: 0.2)$

流 速: $1.8 \mathrm{ml} / \mathrm{min}$

検出器: 日立分光螢光光度計203（キセノンランプ） (Ex 298nm, Em 325nm)

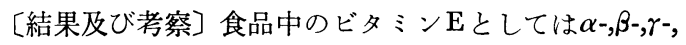

$\delta$-トコフェロールの同族体が含まれているが，血清中り は $\alpha$-トコフェロールが主に検出され, 健常者の場合は 血清 cho值と $\alpha$-トコフェロール值が相関することがす でに報告されている。今回の結果では，疾患を有する者 について子健常者について子同様に血清 Cho 值の上昇 と共に $\boldsymbol{\alpha}$ ートコフェロール值が高くなり, 正の相関 $(\mathbf{r}=$ 0.63）がみられた。このことは, 疾患を有する者の血清 Cho や $\alpha$-トコフェロールの変動が健常者の変動之同 じ傾向であることを表わしていると思われる。又，すべ ての検体を通じて Cho 值が高い血清では TBA 值が高 く, 正の相関 $(r=0.57)$ がみられ，疾患を有する者の 場合に両值共に高い傾向がみられた。同様に, 血清 $\alpha$ トコフェロールが高値の場合に TBA 值が高く, 正の相 関 $(\mathrm{r}=0.64)$ がみられ，特に健常者の場合に $\alpha$-トコフ ェロールと TBA 值が共に低かった。

油脂の加熱によって極性画分螢光量值が増加すること を以前に報告したが，この増加は食用油の酸化を表わ していると考兄られ，今回血清脂質への応用を試みた。 その結果, 血清の螢光量值は健常者で低く, 疾患を有す る者では高値であった。疾患を有する者の平均螢光量値 は健常者の約1.8倍であったが，他方 TBA 值は健常者 の約1.3倍であり, 健常者と疾患を有する者との螢光量 值の差は TBA 值よりも顕著であった。このことは食用 油劣化度の測定方法が血清中の過酸化脂質の測定にも有 用であることを示していると思われる。今後疾患別に更 に検討を重ね，コレステロール・ビタミン $\mathrm{E} ・$ 過酸化脂 質と疾患との関連性を一層明らかにすることによって診 断の一助として有用になるものと思われる。

\footnotetext{
Relationships between cholesterol and tocopherol levels in human serum.

* 大阪市立大学生活科学部

** みどり健康管理センター
} 